\title{
Study of Leachate Contamination in Bantar Gebang Landfill to its Shallow Groundwater Using Natural Isotope Tracers of ${ }^{18} \mathrm{O},{ }^{2} \mathrm{H}$ and ${ }^{3} \mathrm{H}$
}

\author{
E.R. Pujiindiyati and P. Sidauruk \\ Center for Isotopes and Radiation Application-National Nuclear Energy Agency, \\ Jl. Lebak Bulus Raya No.49, Jakarta 12440, Indonesia
}

\section{ARTICLE INFO}

\section{Article history:}

Received 19 June 2014

Received in revised form 13 February 2015

Accepted 22 February 2015

\section{Keywords:}

Deuterium;

Tritium;

Leachate contamination;

Bantar Gebang - Indonesia

\begin{abstract}
A B S T R A C T
Leaching from Bantar Gebang landfill, Jakarta's main municipal landfill, especially from its two waste water treatment plants (plant A in zone-3 and plant B in Sumur Batu) to underlying aquifer has been studied using isotope techniques. The study was based on the abundances of the heavier isotopes in water molocules namely ${ }^{18} \mathrm{O},{ }^{2} \mathrm{H}$ (deuterium) and ${ }^{3} \mathrm{H}$ (tritium). Because both water in the waste-water treatment plants and groundwater have undergone different independent physical processes, it was assumed that each water source has its own typical finger-print in term of the abundances of ${ }^{18} \mathrm{O},{ }^{2} \mathrm{H}$ (deuterium) and ${ }^{3} \mathrm{H}$ (tritium). Leachate from the two waste water treatment plants have higher ${ }^{2} \mathrm{H},{ }^{3} \mathrm{H}$ activities, and physical parameters (EC, TDS, and $\mathrm{pH}$ ) values than those of groundwater samples. Because of the age and size of the two waste water treatment plants are significantly different, it was also observed that the isotope contents of plant $\mathrm{B}$, younger age and smaller size, was relatively lower in ${ }^{2} \mathrm{H}$ values and ${ }^{3} \mathrm{H}$ activities compared to those of plant A. These phenomena have been used to identify the leaching from wastewater treatment plants of Bantar Gebang landfill to the underlying aquifer. During the dry season, it was observed that ${ }^{2} \mathrm{H}$ values in leachate were generally higher than those in rainy season. This result might be due to the extensive methane production in the treatment plants. Conversely, ${ }^{18} \mathrm{O}$-shifting in leachate from local meteoric line indicated that the leachate had experienced evaporation. Buried luminescent paints in the landfill were most likely the source of high tritium activity in leachate. Based on the samples collected from the study area (mostly from dug or bore wells), it was found that the underlying aquifer especially shallow groundwater has been contaminated up to as high as $33 \%$ with leachate.
\end{abstract}

\section{INTRODUCTION}

Bantar Gebang landfill is a large landfill constructed by the municipal goverment of Jakarta. The construction was started in 1986 covering 108 ha and consisting of 5 zones. A main purpose of the construction was to provide solid organic disposal of wastes produced by Jakarta. During its operation as much as 6000 ton/day of solid waste was disposed to the landfill such that it has exceeded its maximum capacity [1]. Next to the area of Bantar

\footnotetext{
* Corresponding author.

E-mail address: ristinpi@batan.go.id

DOI: http://dx.doi.org/10.17146/aij.2015.353
}

Gebang landfill, there is a newer landfill of Sumur Batu which was constructed in 2002 and covered 14.5 ha. This landfill is utilized to dispose of solid waste from Bekasi regency [2]. A sanitary landfill system was applied to Bantar Gebang landfill where waste is isolated from the environment until it is safe [1].

Although these landfills were equipped with a multiple protection system, local residents doubt their environmental health and whether groundwater from the area in surrounding of landfill that they withdraw for daily needs has been contaminated by leachate. Lately, this landfill has often be suggested as the source of 
impacts to local people who demanded for closing it permanently because of the pollution generated by the landfill activities [3].

Investigation of the chemical contents $(\mathrm{Fe}$, $\mathrm{NO}_{2}^{-}, \mathrm{NO}_{3}^{-}, \mathrm{Mn}, \mathrm{Pb}$ ), $\mathrm{COD}, \mathrm{BOD}$, and $\mathrm{pH}$ in Bantar Gebang groundwater was carried out by Matahelumual [4] and Environmental Management Centre [5]. They concluded that the quality of groundwater surrounding landfill was very poor. An unhealthy environment can be identified by the large number of patients suffering diseases such as diarrhea, upper respiratory tract infections, dermatitis, anemia, dysentery, and pneumonia [6].

Many investigations to determine chemical contents in groundwater and river surrounding Bantar Gebang landfill have been conducted whereas the use of natural isotopes for studying pollutant movement is rarely applied. Previously, application of ${ }^{18} \mathrm{O}$ and ${ }^{2} \mathrm{H}$ isotopes as well as nitrates to trace leachate movement to groundwater was conducted by Syafalni [7]. He concluded that high nitrate contents in shallow groundwater samples surrounding the Bantar Gebang landfill probably came from leachate, but he did not estimate how much of the leachate had contributed to the groundwater. Both isotopes and electrical conductivity were also utilized to trace leachate movement streamed through the Cibitung River and its effect on the groundwater nearest to that river [8].

Applications of natural isotopes in landfills for tracing leachate contamination were previously developed in the Metro Manila landfill by Castaneda, et al. [9], in New Zealand by Jessica, et al. [10], in Illinois-USA by Hackeley, et al. [11], in Fresh Kill landfill-Staten Island-New York by Siegel [12].

Similar to other municipal landfill siting, Bantar Gebang landfill is also located in area where an amount of contaminant sources probably exists such as chemical industries, sewage treatment facilities, petrol stations and near to highway run-off. When multiple sources of contaminants are present near a landfill, it may be difficult to interprete the sources of contaminant in monitoring or resident's wells. In that case, natural isotopes can provide independent means for corroborating and refuting information based on conventional investigations. Abundances of natural isotopes (either radioactive or stable) in leachate are unique relative to most natural water such that they can be applied to trace leachate movement in groundwater surrounding landfill $[11,13]$.
The purpose of this study is to confirm whether shallow groundwaters surrounding Bantar Gebang landfill have been contaminated by leachate. Further, mixing percentages of leachate contributing to the groundwater were also estimated. In this study, the natural isotopes used are ${ }^{2} \mathrm{H},{ }^{18} \mathrm{O}$ and ${ }^{3} \mathrm{H}$ in water molecules in conjunction with some field measurements (EC, $\mathrm{pH}$, temperature and TDS).

\section{EXPERIMENTAL METHODS}

\section{Materials}

Materials used in this study were three water standards for ${ }^{18} \mathrm{O}$ and ${ }^{2} \mathrm{H}$ with different isotopic values from LGR (Los Gatos Research), anhydrous $\mathrm{CaSO}_{4}, \mathrm{Na}_{2} \mathrm{O}_{2}$, ultima gold LLT, $\mathrm{CO}_{2}$ gas, 2ml-glass vials, 20ml-glass vials, Anotop 10 membran filter $0.2 \mu \mathrm{m}$

\section{Apparatus}

Apparatus used in this study were Liquid Water Stable Isotope Analyzer LGR (Los Gatos Research)-DT100 which is equipped by vacuum pump, glass column, CTCLC-PAL liquid auto sampler, 1.25 $\mu$ l-syringe, auto sampler tray, polytetraflouroethylene (PTEE) septum and transfer line; distillation apparatus, Liquid Scintillation Analyzer Tri-Carb 2910TR from Perkin Elmer, Magellan Sportrack Global Positioning System and Portable field meters ( $\mathrm{pH}$, temperature, EC and TDS).

\section{Location and sampling method}

Sampling locations for shallow groundwater were selected at a radius approximately $1-2 \mathrm{~km}$ away from Bantar Gebang landfill and collected from resident bore wells. Leachate samples that might be a source of groundwater contamination were also collected from input and output ponds of waste water treatment plant A in zone-3 and plant B in zone-Sumur Batu. Observations were made in March 2013 representing for rainy season and October 2013 representing for dry season. A suite of 18 samples from groundwater, 5 samples from leachate water and 2 samples from river were collected in this observation. Figure 1 shows the sampling location map with dots as groundwater and triangeles as leachate water. Some physical parameters such as electrical conductivity (EC), $\mathrm{pH}$, temperature, and Total Dissolved Solid 
(TDS) were measured as soon as possible in the field.

For sampling water containing ${ }^{18} \mathrm{O}$ and ${ }^{2} \mathrm{H}$ isotopes, the following steps must be performed because water molecules are sensitive to physical processes such as evaporation. About $20 \mathrm{~mL}$ of water samples were added to a plastic bottle by submersing it under the surface of sampled water. The filling of water and closing of plastic bottles should be carried out slowly and carefully to prevent air bubles. Special preparation is not necessary for water sampling needed for tritium analyses. All water samples were analyzed at Laboratory of Hydrology, Center for Isotopes and Radiation Application - National Nuclear Energy Agency (BATAN)

\section{ANALYSIS METHODS}

\section{${ }^{18} \mathrm{O}$ and ${ }^{2} \mathrm{H}$ analyses}

Water samples, which were filtered if turbid or contained sediment and shaken to equilibrium, were pipetted with a fresh tip for each sample, with as much as $1 \mathrm{ml}$, dispensed into appropriate glass vial on the autosampler tray. The filled vials were immediately capped. The same procedure was also applied to three water standards consisting of different isotopic composition of ${ }^{18} \mathrm{O}$ and ${ }^{2} \mathrm{H}$ with abundance range from depleted to enriched. A reference standard for oxygen and deuterium in water is an international standard of VSMOW (Vienna Standard Mean Ocean Water) $[13,14]$. Samples and standard solutions in the auto sampler tray were arranged in the order such that every three standards were followed by five samples. ${ }^{18} \mathrm{O}$ and ${ }^{2} \mathrm{H}$ isotopes in the samples and standard solutions were measured by a liquid water stable isotope analyzer LGR-DT100 connected to CTC LC-PAL Auto Sampler through PTEE transfer line. The molecular concentration of ${ }^{2} \mathrm{HHO}, \mathrm{HH}^{18} \mathrm{O}$ and $\mathrm{HHO}$ were calculated by measuring the absorbance at wavelength of $1390 \mathrm{~nm}$. Each sample was measured six times to obtain good statistical values and the measurement results were calculated by excel programme [14].

Isotope ratio value was expressed with delta $\delta$ (delta) notation in per mill $(\% 00)$ and defined as follow [13,14]: $\quad \delta=\frac{R_{\text {measured }}-R_{V S M O W}}{R_{V S M O W}}$

" $\mathrm{R}$ " notation is, in the case of water, the ${ }^{18} \mathrm{O} /{ }^{16} \mathrm{O}$ or ${ }^{2} \mathrm{H} /{ }^{1} \mathrm{H}$.

\section{Tritium analysis}

First, the water samples from the field were distilled to remove any interfering minerals. The distilled water sample of $600 \mathrm{~mL}$ was weighed, $3 \mathrm{mg}$ of $\mathrm{N}_{2} \mathrm{O}_{2}$ was added and transferred into 14 electrolytic cells placed in cooling water bath at $0{ }^{\circ} \mathrm{C}$. Each cell in series was connected with electric current. After 10 days, the volume of sample would only be about $20 \mathrm{~mL}$, meaning the tritium content was 30 times enriched. Then, the sample was neutralized with $\mathrm{CO}_{2}$ and distilled for purification. Finally, the $10 \mathrm{ml}$ of distilled sample was pipetted accurately and poured into vial glass and mixed with $11 \mathrm{~mL}$ of scintillator solution of ULTIMA Gold Llt then counted using Liquid Scintillation Analyzer (LSA).

Tritium concentration which decreases exponentially, is calculated according to the following decay formula:

$$
C_{t}=C_{0} e^{\frac{-0.693}{t_{1} / 2} T}
$$

Tritium concentration $\left({ }^{3} \mathrm{H}\right)$ are expressed as Tritium Unit (TU) $1 \mathrm{TU}$ where $1 \mathrm{TU}$ is 1 tritium atom per 1018 hydrogen atoms, $\mathrm{T}$ is decay time in year, $t_{1 / 2}=12.34$ years is the half-life of tritium, $C_{o}$ is initial concentration of tritium and $C_{t}$ is tritium concentration of groundwater $[13,15]$.

\section{RESULTS AND DISCUSSION}

This study emphasized monitoring of some natural isotopes either radioactive, such as ${ }^{3} \mathrm{H}$ (tritium) and natural isotopes such as ${ }^{2} \mathrm{H}$ and ${ }^{18} \mathrm{O}$, toward shallow groundwater in the radius range of $2 \mathrm{~km}$ from Bantar Gebang landfill. The term of shallow groundwater refers to the unconfined aquifer system with the depth scale around $0-40 \mathrm{~m}$ [16]. Selected sites of Bantar Gebang shallow groundwater were mapped as depicted in Fig. 1 while water sample depths and their coordinates were shown at Table 1. 
Table 1. Sampling locations for leachates and shallow groundwater.

\begin{tabular}{|c|c|c|c|c|}
\hline \multirow[t]{2}{*}{ No } & \multirow[t]{2}{*}{ Sample ID } & \multirow[t]{2}{*}{ Sample type - depth } & \multicolumn{2}{|c|}{ Coordinates } \\
\hline & & & Longitude & Latitude \\
\hline 1 & BG-1a & groundwater $-9 \mathrm{~m}$ & $06^{\circ} 20^{\prime} 58^{\prime \prime}$ & $106^{\circ} 59^{\prime} 38^{\prime \prime}$ \\
\hline 2 & BG-1b $6 \mathrm{~m}$ & groundwater- $6 \mathrm{~m}$ & $06^{\circ} 21^{\prime} 9.3^{\prime \prime}$ & $106^{\circ} 59^{\prime} 49.7 "$ \\
\hline 3 & BG- $1 \mathrm{~b} 15 \mathrm{~m}$ & groundwater $-15 \mathrm{~m}$ & $06^{\circ} 21^{\prime} 9.3^{\prime \prime}$ & $106^{\circ} 59^{\prime} 49.7 "$ \\
\hline 4 & BG-1c & river water - surface & $06^{\circ} 20^{\prime} 42.6^{\prime \prime}$ & $106^{\circ} 5934.4 "$ \\
\hline 5 & BG-1d & leachate outlet-plant A & $06^{\circ} 21^{\prime} 9.3^{\prime \prime}$ & $106^{\circ} 59^{\prime} 49.7 "$ \\
\hline 6 & BG-1e & leachate inlet- plant A & $06^{\circ} 21^{\prime} 9.3^{\prime \prime}$ & $106^{\circ} 59^{\prime} 49.7^{\prime \prime}$ \\
\hline 7 & BG-1f & leachate effluent-plant A & $06^{\circ} 20^{\prime} 50.1^{\prime \prime}$ & $106^{\circ} 59^{\prime} 37.4 "$ \\
\hline 8 & BG-2 & groundwater $-10 \mathrm{~m}$ & $06^{\circ} 20^{\prime} 55.2^{\prime \prime}$ & $106^{\circ} 59^{\prime} 12.5^{\prime \prime}$ \\
\hline 9 & BG-3 & groundwater $-12 \mathrm{~m}$ & $06^{\circ} 200^{\prime} 28.9^{\prime \prime}$ & $106^{\circ} 59^{\prime} 23.9^{\prime \prime}$ \\
\hline 10 & BG-4a & groundwater $-5 \mathrm{~m}$ & $06^{\circ} 20^{\prime} 32.1^{\prime \prime}$ & $107^{\circ} 00^{\prime} 12.0^{\prime \prime}$ \\
\hline 11 & BG- $4 b$ & groundwater $-15 \mathrm{~m}$ & $06^{\circ} 20^{\prime} 32.7^{\prime \prime}$ & $107^{\circ} 005.6^{\prime \prime}$ \\
\hline 12 & BG-4c & leachate outlet-plant B & $06^{\circ} 20^{\prime} 32.7^{\prime \prime}$ & $107^{\circ} 00^{\prime} 5.6^{\prime \prime}$ \\
\hline 13 & BG-4d & river water - surface & $06^{\circ} 20^{\prime} 32.7^{\prime \prime}$ & $107^{\circ} 00^{\prime} 5.6^{\prime \prime}$ \\
\hline 14 & BG-4e & leachate inlet-plant B & $06^{\circ} 20^{\prime} 35.1^{\prime \prime}$ & $107^{\circ} 00^{\prime} 10.2^{\prime \prime}$ \\
\hline 15 & BG-5 & groundwater $-15 \mathrm{~m}$ & $06^{\circ} 20^{\prime} 59.6^{\prime \prime}$ & $107^{\circ} 00^{\prime} 11.0^{\prime \prime}$ \\
\hline 16 & BG-6 & groundwater - $18 \mathrm{~m}$ & $06^{\circ} 21^{\prime} 32.9^{\prime \prime}$ & $106^{\circ} 59^{\prime} 34.8^{\prime \prime}$ \\
\hline 17 & BG-7 & groundwater $-12 \mathrm{~m}$ & $06^{\circ} 21^{\prime} 15.1^{\prime \prime}$ & $106^{\circ} 58^{\prime} 53.3^{\prime \prime}$ \\
\hline 18 & BG-8 & groundwater - $20 \mathrm{~m}$ & $06^{\circ} 20^{\prime} 48.5^{\prime \prime}$ & $106^{\circ} 58^{\prime} 41.4^{\prime \prime}$ \\
\hline 19 & BG-9 & groundwater $-20 \mathrm{~m}$ & $06^{\circ} 20^{\prime} 9.7^{\prime \prime}$ & $106^{\circ} 58^{\prime} 47.6^{\prime \prime}$ \\
\hline 20 & BG-10 & groundwater - $18 \mathrm{~m}$ & $06^{\circ} 19^{\prime} 58.6^{\prime \prime}$ & $106^{\circ} 59^{\prime} 30.0^{\prime \prime}$ \\
\hline 21 & BG-11 & groundwater $-12 \mathrm{~m}$ & $06^{\circ} 20^{\prime} 1.1^{\prime \prime}$ & $107^{\circ} 00^{\prime} 2.4^{\prime \prime}$ \\
\hline 22 & BG-12 & groundwater - $15 \mathrm{~m}$ & $06^{\circ} 20^{\prime} 25.8^{\prime \prime}$ & $107^{\circ} 00^{\prime} 34.5^{\prime \prime}$ \\
\hline 23 & BG-13 & groundwater $-12 \mathrm{~m}$ & $06^{\circ} 20^{\prime} 54.1^{\prime \prime}$ & $107^{\circ} 00^{\prime} 41.7^{\prime \prime}$ \\
\hline 24 & BG-14 & groundwater $-12 \mathrm{~m}$ & $06^{\circ} 21^{\prime} 25.5^{\prime \prime}$ & $107^{\circ} 00^{\prime} 36.1^{\prime \prime}$ \\
\hline 25 & BG-15 & groundwater $-10 \mathrm{~m}$ & $06^{\circ} 21^{\prime} 50.4^{\prime \prime}$ & $106^{\circ} 59^{\prime} 59.8^{\prime \prime}$ \\
\hline
\end{tabular}

A: waste water treatment plant in zone-3 of Bantar Gebang B: waste water treatment plant in zone-Sumur Batu

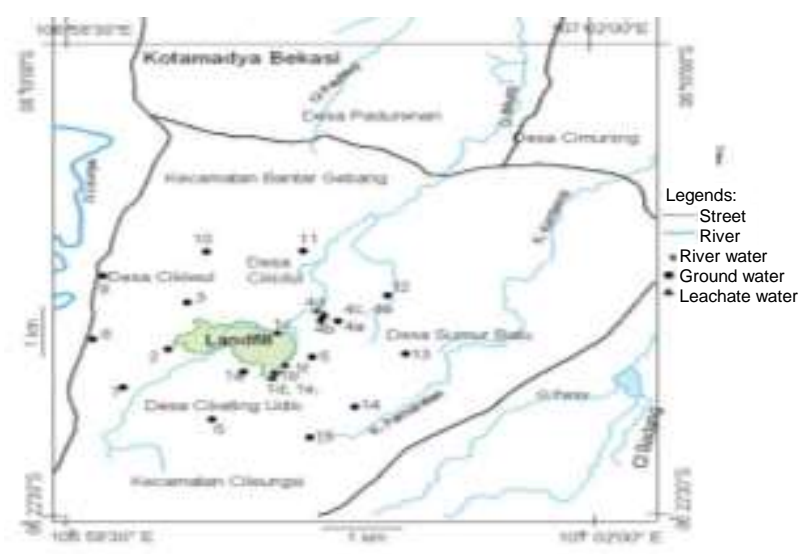

Fig. 1. Map of sampling location for shallow groundwater in Bantar Gebang landfill.

\section{Groundwater quality}

Table 2 shows the average electrical conductivity $(\mu \mathrm{S} / \mathrm{cm})$ for each of monitoring well and shallow groundwater, which is closely related to the total dissolved solids (TDS) in the water as an indicator for quality of water. It appears that monitoring well of BG-1b with depth of $6 \mathrm{~m}$ (open dug well) shows the high electrical conductivity (3070 $\mu \mathrm{S} / \mathrm{cm}$ ) indicating, leachate infiltration to this well. The electrical conductivity $(3100 \mu \mathrm{S} / \mathrm{cm})$ at
BG-1b with depth $15 \mathrm{~m}$ (bore well) apparently confirmed the downward movement of leachate coming from plant $\mathrm{A}$.

Table 2. Measured physical parameters in the field.

\begin{tabular}{|c|c|c|c|c|c|c|c|c|}
\hline No & $\begin{array}{c}\text { Rainy } \\
\text { season } \\
\mathrm{T} \\
\left({ }^{\circ} \mathrm{C}\right) \\
\end{array}$ & $\begin{array}{c}\text { Dry } \\
\text { season } \\
\mathrm{pH}\end{array}$ & $\begin{array}{c}\mathrm{EC} \\
(\mathrm{mS} / \mathrm{cm})\end{array}$ & $\begin{array}{l}\text { TDS } \\
(\mathrm{ppt})\end{array}$ & $\begin{array}{c}\mathrm{T} \\
\left({ }^{\circ} \mathrm{C}\right) \\
\end{array}$ & $\mathrm{pH}$ & $\begin{array}{c}\mathrm{EC} \\
(\mathrm{mS} / \mathrm{cm})\end{array}$ & $\begin{array}{l}\text { TDS } \\
\text { (ppt) }\end{array}$ \\
\hline BG-1a & 29.7 & 6.21 & 0.30 & 0.13 & 30.8 & 6.37 & 0.33 & 0.16 \\
\hline $\begin{array}{l}\text { BG-1b } \\
6 \mathrm{~m}\end{array}$ & 30.6 & 5.77 & 3.07 & 1.53 & $*$ & & & \\
\hline $\begin{array}{l}\text { BG-1b } \\
15 \mathrm{~m}\end{array}$ & n.a & & & & 30.4 & 5.88 & 3.10 & 1.54 \\
\hline BG-1c & 31.3 & 7.18 & 0.38 & 0.19 & 30.6 & 7.22 & 0.73 & 0.37 \\
\hline BG-1d & 31 & 7.14 & 6.72 & 3.36 & 30.5 & 7.61 & 10.88 & 5.45 \\
\hline BG-1e & 37.2 & 8.13 & $>20$ & $>10$ & 35.2 & 8.04 & $>20$ & $>10$ \\
\hline BG-1f & 33.4 & 8.07 & 11.62 & 5.80 & 32 & 8.00 & $>20$ & $>10$ \\
\hline BG-2 & 31.1 & 5.19 & 0.73 & 0.36 & 30.5 & 5.28 & 0.63 & 0.31 \\
\hline BG-3 & 30.8 & 5.10 & 0.18 & 0.09 & 35.1 & 5.32 & 0.23 & 0.11 \\
\hline BG-4a & 28 & 6.05 & 0.08 & 0.04 & $*$ & & & \\
\hline BG-4b & 31.2 & 6.65 & 1.30 & 0.05 & 32.2 & 6.34 & 1.39 & 0.69 \\
\hline BG-4c & 30.5 & 7.88 & 2.30 & 1.17 & 31 & 8.58 & 1.89 & 0.94 \\
\hline BG-4d & 29.9 & 7.72 & 3.01 & 1.52 & 33.2 & 7.99 & 8.04 & 4.03 \\
\hline BG-4e & 29.8 & 8.16 & 4.73 & 2.36 & 34.1 & 8.18 & 4.09 & 2.04 \\
\hline BG-5 & 29.4 & 6.64 & 0.36 & 0.18 & 30.2 & 5.90 & 0.35 & 0.17 \\
\hline BG-6 & 29.8 & 5.08 & 0.17 & 0.08 & 30.2 & 4.36 & 0.20 & 0.09 \\
\hline BG-7 & 30.1 & 5.2 & 0.22 & 0.10 & 30 & 4.55 & 0.14 & 0.07 \\
\hline BG-8 & 30.2 & 6.3 & 0.34 & 0.17 & 29.7 & 6.58 & 0.30 & 0.15 \\
\hline BG-9 & 30.2 & 5.49 & 0.23 & 0.11 & 30 & 4.55 & 0.14 & 0.07 \\
\hline BG-10 & 30.4 & 6.24 & 0.22 & 0.11 & 30.3 & 5.31 & 0.12 & 0.06 \\
\hline BG-11 & 30.9 & 5.85 & 0.37 & 0.18 & 29.9 & 5.48 & 0.33 & 0.26 \\
\hline BG-12 & 30.5 & 5.78 & 0.16 & 0.07 & 29.5 & 5.07 & 0.15 & 0.07 \\
\hline BG-13 & 27.6 & 5.20 & 0.20 & 0.10 & 29.5 & 5.51 & 0.20 & 0.10 \\
\hline BG-14 & 29 & 5.19 & 0.13 & 0.06 & 30.8 & 5.79 & 0.18 & 0.08 \\
\hline BG-15 & 29.6 & 4.54 & 0.25 & 0.12 & 29.2 & 4.40 & 0.22 & 0.11 \\
\hline
\end{tabular}

Both wells are located in the same zone with a distance of around $3 \mathrm{~m}$ from inlet pond which had an extremely high EC value of more than $20.000 \mu \mathrm{S} / \mathrm{cm}$. Except for the monitoring wells in landfill area, most shallow groundwater surounding the Bantar Gebang landfill showed EC values in the range of 160 to $730 \mu \mathrm{S} / \mathrm{cm}$ (TDS is $70 \mathrm{mg} / \mathrm{L}$ to $360 \mathrm{mg} / \mathrm{L}$ ) in rainy season that did not significantly change.

In contrast, leachate movement was not detected at monitoring well BG-4a in plant B (open dug well with depth of $5 \mathrm{~m}$ and approximately $10 \mathrm{~m}$ from inlet pond) which still contains normal groundwater based on EC values. However, leachate movement was observed at BG-4b (bore well with depth of $15 \mathrm{~m}$ and $3 \mathrm{~m}$ from inlet pond) based on EC values rather higher than that of other shallow groundwater, even though it is still much lower than that of bore well BG-1b at waste water treatment plant A.

From the viewpoint of TDS, the leachate from inlet pond at plant A represented the highest TDS of more than $10.000 \mathrm{mg} / \mathrm{L}$, while TDS from leachate in plant B was $2360 \mathrm{mg} / \mathrm{L}$. The higher TDS of leachate in plant A might be due to its longer 
operation activity since 1986 compared to plant B starting the operation since 2002. The higher TDS in leachate might be caused by high cation contents of $\mathrm{Na}, \mathrm{K}, \mathrm{Ca}, \mathrm{Mg}$ absorbed in clay minerals (used as cover of the trash) which could be readiy exchanged with amonium released in the leachates [17].

Most $\mathrm{pH}$ values for shalow groundwater, except monitoring wells, an average $\mathrm{pH}$ of 5.68 with the lowest one being 4.54 at BG-15 as observed in the rainy season. The average $\mathrm{pH}$ was likely to decrease slightly to 5.36 in dry season. The low $\mathrm{pH}$ of natural groundwater is primarily due to $\mathrm{pH}$ of rainfall and the lack of other soluble minerals in the aquifer material. The significantly higher $\mathrm{pH}$ (> 7.1) in the leachate is somewhat unexpected because large amounts of $\mathrm{CO}_{2}$ generated from degradation of organic materials should lower the $\mathrm{pH}$. The increasing $\mathrm{pH}$ is mostly due to the ammonium resulting from the decays of biomass organic $\mathrm{N}$, due to generation of carbon dioxide and consumption of hydrogen for the formation of methane [13,17].

Regulation of Ministry of Health of Indonesia No.416/Menkes/Per/IX/1990, safe drinking water should meet a requirement of TDS level is $500 \mathrm{mg} / \mathrm{L}$ and $\mathrm{pH}$ range is 6.5 to 8.5 [4]. Although most shallow groundwater showed TDS values lower than required by Ministry of Health, the $\mathrm{pH}$ values did not meet the requirements for drinking water supply. Based on field data above, both monitoring wells in plant $\mathrm{A}$ had been influenced by leachate contamination.

\section{Groundwater interrelationship}

\section{Deuterium and Oxygen-18}

Table 3 shows measurement results of $\delta{ }^{18} \mathrm{O}$, $\delta{ }^{2} \mathrm{H}$ and ${ }^{3} \mathrm{H}$ isotopes of water samples collected in the rainy and dry seasons, while the relationship between $\delta{ }^{18} \mathrm{O}$ and $\delta{ }^{2} \mathrm{H}$ in the rainy and dry seasons is depicted in Figs. 2 and 3, respectively. Based on the equation in Fig. 2, most of $\delta{ }^{2} \mathrm{H}$ in the shallow groundwater collected in the rainy season at $\delta{ }^{18} \mathrm{O}=0$ were 6.38 . The slope of the equation of 7.4 is quite close to the Local Meteoric Water Line (LMWL) of $\delta{ }^{2} \mathrm{H}=7.8 \delta{ }^{18} \mathrm{O}$ +13 with a slope of 7.8 which was obtained from measurements of rainfall collected monthly at different elevations starting from Tongkol-Jakarta (at elevation of $10 \mathrm{~m}$ ) to Puncak-Bogor (at elevation of $1020 \mathrm{~m}$ ) as reported by Wandowo et.al (2002) [16].
Table 3. Result of ${ }^{18} \mathrm{O},{ }^{2} \mathrm{H}$ and ${ }^{3} \mathrm{H}$ isotopes from water samples collected in rainy and dry season.

\begin{tabular}{|c|c|c|c|c|c|}
\hline \multirow[t]{2}{*}{ No } & \multicolumn{3}{|c|}{ Rainy season } & \multicolumn{2}{|c|}{ Dry season } \\
\hline & $\begin{array}{l}\delta^{18} \mathrm{O} \\
(\% 0)\end{array}$ & $\begin{array}{l}\delta^{2} \mathrm{H} \\
(\% 0)\end{array}$ & $\begin{array}{c}{ }^{3} \mathrm{H} \\
(\mathrm{TU})\end{array}$ & $\begin{array}{l}\delta^{18} \mathrm{O} \\
(\%)\end{array}$ & $\begin{array}{l}\delta^{2} \mathrm{H} \\
(\% 0)\end{array}$ \\
\hline BG-1a & -5.96 & -37.42 & 14.92 & -6.26 & -37.9 \\
\hline BG-1b 6m & -6.02 & -29.80 & 76.66 & n.a & n.a \\
\hline BG-1b $15 \mathrm{~m}$ & n.a & n.a & n.a & -5.81 & -30.6 \\
\hline BG-1c & -6.14 & -30.93 & 8.43 & -3.04 & -23.1 \\
\hline BG-1d & -5.43 & -21.87 & 50.90 & -0.42 & -3.6 \\
\hline BG-1e & -5.93 & +7.86 & 493.89 & +0.67 & +10.3 \\
\hline BG-1f & -5.65 & -17.51 & 116.07 & -4.89 & -5.0 \\
\hline BG-2 & -6.68 & -45.00 & 7.23 & -7.23 & -44.1 \\
\hline BG-3 & -6.06 & -41.24 & 6.93 & -6.92 & -43.1 \\
\hline BG-4a & -6.64 & -42.66 & 8.65 & n.a & n.a \\
\hline BG-4b & -6.31 & -36.57 & 19.29 & -6.71 & -37.6 \\
\hline BG-4c & -5.32 & -25.68 & 9.55 & -0.98 & -21.1 \\
\hline BG-4d & -6.13 & -28.96 & 33.49 & -4.97 & -25.6 \\
\hline BG-4e & -5.98 & -23.92 & 10.65 & -2.37 & -18.9 \\
\hline BG-5 & -5.40 & -33.95 & 7.83 & -6.82 & -39.3 \\
\hline BG-6 & -6.31 & -40.72 & 7.59 & -7.20 & -42.5 \\
\hline BG-7 & -5.73 & -37.94 & 7.05 & -7.16 & -42.8 \\
\hline BG-8 & -6.26 & -41.09 & n.a & -7.28 & -43.1 \\
\hline BG-9 & -7.20 & -46.58 & $\mathrm{n} . \mathrm{a}$ & -7.27 & -48.3 \\
\hline BG-10 & -5.59 & -35.34 & 16.76 & -7.39 & -46.6 \\
\hline BG-11 & -6.07 & -40.25 & 5.19 & -6.62 & -43.8 \\
\hline BG-12 & -6.22 & -38.66 & n.a & -6.26 & -41.8 \\
\hline BG-13 & -6.50 & -43.49 & 6.96 & -6.38 & -41.7 \\
\hline BG-14 & -6.15 & -39.71 & 6.59 & -6.58 & -41.2 \\
\hline BG-15 & -6.62 & -41.54 & n.a & -6.83 & -46.2 \\
\hline
\end{tabular}

n.a: not analyzed

This result shows little evidence of evaporation occuring during rainy season. Known characteristics of $\delta{ }^{18} \mathrm{O}$ and $\delta{ }^{2} \mathrm{H}$ in meteoric waters in the local area is essential in assigning the base line rate for groundwater recharge. It appears that there are some physical and chemical processes that affect the isotopic composition of the water corresponding to precipitation that could deviate from the meteoric line. The Meteoric Water Line (MWL) can indicate how isotopes of the water are affected by certain physicochemical processes such as evaporation, high and low temperature exchange reactions with rock minerals, hydration of silicates, $\mathrm{CO}_{2}$ exchange reactions, $\mathrm{H}_{2} \mathrm{~S}$ exchange reactions and methanogenesis [13,18].

The extent to which the slope of MWL shifts was clearly indicated by water samples collected in the major dry season as depicted in Fig. 3 where the data points were distributed along the line of $\delta$ ${ }^{2} \mathrm{H}=6.98 \delta{ }^{18} \mathrm{O}+5.54$. The decreasing slope assumed a strong evaporation area. A mixing process between direct rainwater infiltration and evaporated water due to hot landscapes during dry season had shifted values toward more enriched values of both isotopes in the groundwater samples. Evaporation could occur from surface water during run off prior to infiltration, in the unzaturated zone itself or in the water table, respectively [13].

The composition of ${ }^{2} \mathrm{H}$ in leachate collected from the inlet pond, the outlet pond and the leachate 
run off from plant A indicated enriched values of ${ }^{2} \mathrm{H}$ with ranges of $-21.87 \%$ to $+7.86 \%$ for the rainy season and $-5 \%$ to $+10.3 \%$ for the dry season, respectively. Significant enrichment in deuterium in the leachate was also observed for plant B with ranges of $-25.68 \%$ to $-23.92 \%$ for the rainy season and $-21.1 \%$ to $-18.9 \%$ for the dry season, respectively. It appears that the extent of deuterium enrichment in both active landfills increased significantly for the leachate sampled in the dry season compared to the rainy season. This result was likely due to high temperatures that caused rapid evaporation and minimal influences of groundwater and surface water [13].

Deuterium values for leachate varied considerably between the two waste water treatment ponds, where the leachate from plant A in zone-3 was much higher and had a wider range than those of plant B in zone-Sumur Batu. The higher enriched deuterium values of leachate at plant A were likely due to one or a combination of two effects. The first is due to pure leachate samples that might be without any influences from river water which is located at the distance of more than $1 \mathrm{~km}$ whereas leachate from plant $\mathrm{B}$ is approximately $5 \mathrm{~m}$-distance from the river as shown in Fig. 1. The second is due to increased methanogenesis activity caused by gradual enrichment of existing organic source in older plant A [1].

The Cibitung River that runs beside the two active plants also contributed to enrich deuterium values in either rainy or dry season. However, the increase of deuterium values was significant for samples collected in the dry season.

The highly enriched deuterium in leachate compared to most natural groundwater was mainly affected by production of enormous quantities of methane by microbes (or methanogenesis) at landfill sites as described previously. This process requires highly reducing conditions that exclude atmospheric $\mathrm{O}_{2}$ and high content of organic carbon which is generally available in the leachate. The microbial concentrations under reducing conditions is very high such that it can cause large isotopic fractionation. In this case, the microbes playing an important role in isotopic fractionation by breaking of $\mathrm{H}-\mathrm{O}$ bonds in $\mathrm{H}_{2} \mathrm{O}$ compounds (in leachate water) prefer using the lighter hydrogen isotopes $\left({ }^{1} \mathrm{H}\right)$ when producing $\mathrm{CH}_{4}$ such that ${ }^{2} \mathrm{H}$ composition of remaining water (deuterium in $\mathrm{H}_{2} \mathrm{O}$ in leachate) is highly enriched $[11,13,18]$.

Another process associated with enrichment of ${ }^{2} \mathrm{H}$ isotope in landfill site is isotopic exchange reaction between $\mathrm{H}_{2} \mathrm{O}$ and $\mathrm{H}_{2} \mathrm{~S}$ that would occur during $\mathrm{SO}_{4}$ reduction in landfill. However, the main cause in increasing enriched deuterium of leachate is due to methanogenesis process $[11,13]$.

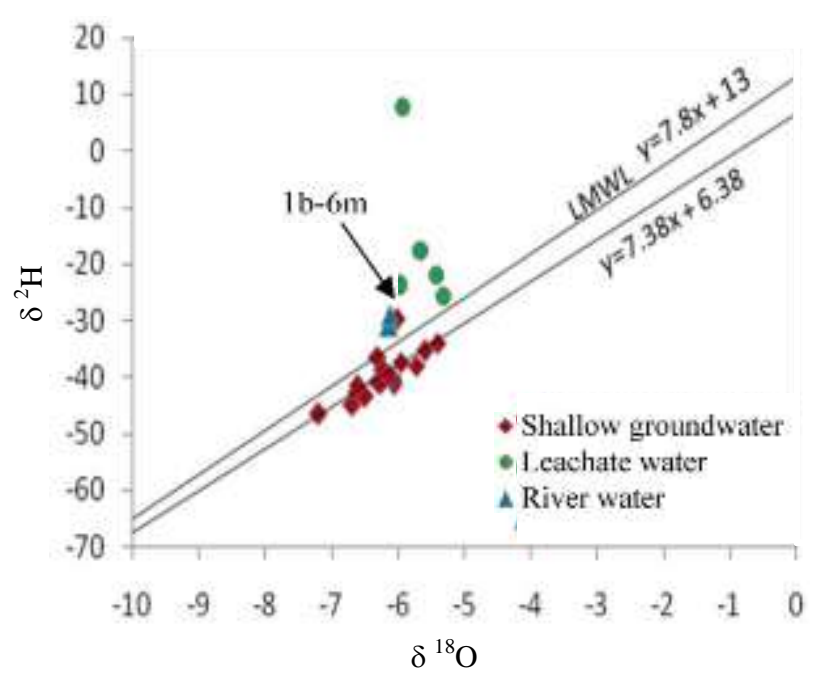

Fig. 2. Relationship between ${ }^{18} \mathrm{O}$ and ${ }^{2} \mathrm{H}$ from water samples collected in wet season.

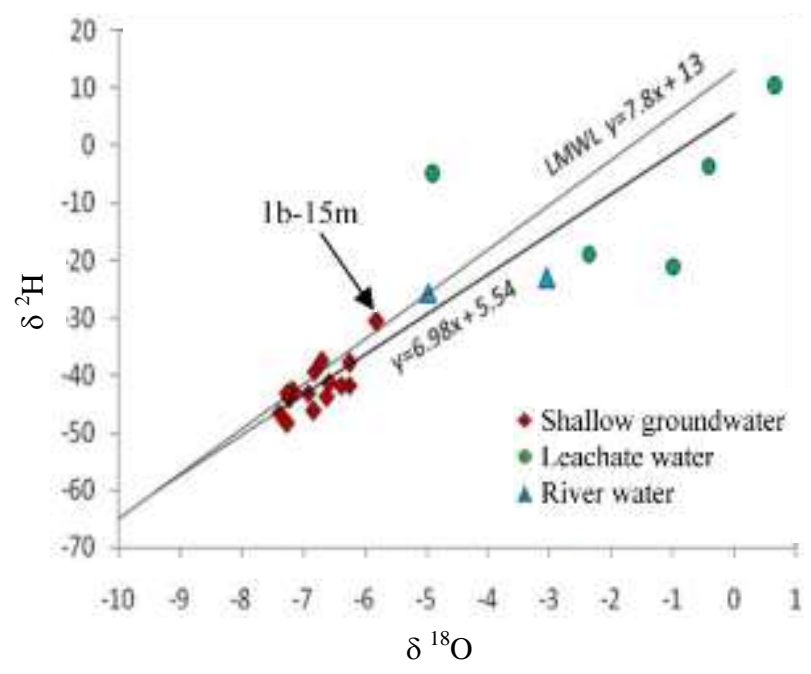

Fig. 3. Relationship between ${ }^{18} \mathrm{O}$ and ${ }^{2} \mathrm{H}$ from water samples collected in dry season.

In contrast to deuterium, the isotopic composition of oxygen in the leachate was not influenced by microbial activity in landfill. The higher enriched oxygen values in leachate than those of most natural groundwater might be due to an evaporation effect in the closed system of leachate ponds. Moreover, the effect of evaporation in oxygen isotope clearly appeared in leachate taken during dry season as seen in Table 3 . The ${ }^{18} \mathrm{O}$ values showed a narrow range from $-5.32 \%$ to $-5.98 \%$ and from $0.67 \%$ to $-4.89 \%$ for the rainy season and the dry season, respectively. Similar to the case of enrichment of ${ }^{18} \mathrm{O}$, the river seemed to have the higher ${ }^{18} \mathrm{O}$ values in the dry season than those of the rainy season. It was mainly caused by hot atmosphere in dry season and more 
stagnant river flow such that greater evaporation would occur.

Deuterium values from leachate were more enriched than those of groundwater indicating isotopic exchange between leachate water and methane. Both monitoring wells in plant $\mathrm{A}$ had been influenced by leachate movement based on the more enriched deuterium values.

\section{Tritium}

The analyses results of tritium content in leachate collected from plant A in zone-3 and plant $\mathrm{B}$ in zone-Sumur Batu as well as its surounding groundwaters were presented in Table 3. It appears that the tritium content in the leachate samples was higher than that of the native groundwater. Leachate from plant $\mathrm{A}$ showed a wider range of tritium content (50.90 TU to $493 \mathrm{TU}$ ) and much higher than those of plant B. This tritium content in the leachate is comparable to values from the Breitenau Experimental Landfill in Austria about 2000 TU with a few leachate samples showing 3000 TU. In comparison, three different municipal landfills in Illinois had a range of $227 \mathrm{TU}$ to $8000 \mathrm{TU}$ [11] and a municipal landfill in Metro Manila-Philippines had values about 150 TU to 820 TU [9]. The high tritium content of leachate from plant A was probably due to the older municipal landfill such that part of soluble materials in leachate was relatively higher even compared to the peak of concentration reached in 1963 of around 180.2 TU in Jakarta, the nearest station from studied area. The 1963 high values were attributed to the atmospheric ${ }^{3} \mathrm{H}$ from bomb tests between 1954-1963 [15].

The tritium content of shallow groundwater samples showed a wide variation from 5.19 TU to 76.66 TU. The high level of tritium up to $5.5 \mathrm{TU}$ in 1978 and 1.9 TU in 1987 from precipitation [15] infiltrating some groundwater samples might be as an indication of leachate contribution. However, the high tritium content of leachate cannot be explained solely by tritium input from local precipitation after thermonuclear bomb test, because tritium from precipitation in Jakarta station has decreased to $5.3 \mathrm{TU}$ since 1978 [15].

Therefore, the most probable source of tritium in leachate comes from gaseous tritium light devices (GTLDs), luminescent paints used in watch dials, compasses, lights for map reading, in self-illuminated exit signs and clocks as well as other luminescent dials that could easily be disposed of in municipal landfills. These luminescent paints contain tritiated hydrocarbons that could biodegradable in landfill and add to overall tritium contents [11,13].

Tritium activity in leachate was much higher than those of groundwater. The activity increased in the leachate from older plant A. Monitoring wells had higher tritium activities that was probably due to leachate contamination.

\section{Mixing of leachate to shallow groundwater}

The general equation for mixing between two water sources with different isotopic contents is expressed as follows:

$$
\delta^{2} \mathrm{H}=\delta_{\mathrm{a}}{ }^{2} \mathrm{Hx}+\delta_{\mathrm{b}}{ }^{2} \mathrm{H}(1-\mathrm{x})
$$

Where $\mathrm{a}$ and $\mathrm{b}$ are type of two solutions, $\mathrm{x}$ and (1-x) are mole fraction of $\mathrm{a}$ and $\mathrm{b}$, and $\delta{ }^{2} \mathrm{H}$ is a measured isotope value $[19,20]$. In the case of leachate migration to groundwater, solution a is leachate as source of contaminant and solution $b$ is pure water of rainwater. Table 4 shows estimated percentages of leachate contribution to some shallow wells calculated by the equation above. Tritium activities in the table represented as one of qualitative parameter of leachate migration and were used as comparison of the quantitative mixing of some water samples with leachate.

To estimate mixing percentages (as $\mathrm{x}$ in above equation) of leachate into groundwater, it is necessary to have a $\delta{ }^{2} \mathrm{H}$ value for local rainwater. The rainwater recharging to groundwater reserves its $\delta{ }^{2} \mathrm{H}$ isotopic composition in groundwater as long as no evaporation occurs. It means that average value of $\delta^{2} \mathrm{H}$ from shallow groundwater is represented by $\delta{ }^{2} \mathrm{H}$ of the recharging rainwater [13]. From Table 3, the average of $\delta \quad{ }^{2} \mathrm{H}$ from shallow groundwater in the rainy season is $-39.53 \%$. Therefore, rainwater at an elevation of $600 \mathrm{~m}$ with $\delta{ }^{2} \mathrm{H}$ value of $-39.3 \%$ (as $\delta_{\mathrm{b}}{ }^{2} \mathrm{H}$ in above equation), as reported by Wandowo et.al, is estimated as rainwater recharging into Bantar Gebang shallow groundwater [16]. The average of $\delta \quad{ }^{2} \mathrm{H}$ value in leachate (as $\delta_{\mathrm{a}}{ }^{2} \mathrm{H}$ in above equation) was obtained with the assumption that the nearest leachate from run off and ponds were the main source, except for river which its average of $\delta{ }^{2} \mathrm{H}$ was calculated from all input leachate. 
Table 4. Result for mixing percentage of some supposed wells contaminated by leachate in rainy season.

\begin{tabular}{lcccc}
\hline \multicolumn{1}{c}{ Sample ID } & $\begin{array}{c}\text { Average of } \\
\delta{ }^{2} \mathrm{H} \text { in leachate } \\
(\%)\end{array}$ & $\begin{array}{c}\delta^{2} \mathrm{H} \\
(\%)\end{array}$ & $\begin{array}{c}{ }^{3} \mathrm{H} \\
(\mathrm{TU})\end{array}$ & $\begin{array}{c}\text { Mixing with } \\
\text { leachate } \\
(\%)\end{array}$ \\
\hline $\begin{array}{l}\text { BG-4d } \\
\text { (river) }\end{array}$ & -17.66 & -28.96 & 33.49 & 47.77 \\
BG 1b-6m & -10.51 & -29.80 & 76.66 & 32.99 \\
BG 1b-15m & -10.51 & -30.60 & n.a & 30.22 \\
BG-1c & -10.51 & -30.93 & 8.43 & 29.07 \\
(river) & -24.80 & -36.57 & 19.29 & 18.83 \\
BG-4b & -10.51 & -33.95 & 7.83 & 18.58 \\
BG-5 & -10.51 & -35.34 & 16.65 & 13.75 \\
BG-10 & -10.51 & -37.42 & 14.92 & 6.53 \\
BG-1a & & & & \\
\hline
\end{tabular}

n.a $=$ not analyzed

Table 4 shows that the highest percentage (32.99\%) of leachate contribution to groundwater was in the $6 \mathrm{~m}$-monitoring well of plant $\mathrm{A}$ located approximately $3 \mathrm{~m}$ from the leachate ponds. Moreover, adding leachate to this monitoring well was also confirmed by the highest tritium content. Downward leachate movement as much as $30.22 \%$ was also observed in 15 m-bore well collected in the dry season. Although it was not as high as mixing leachate in plant $\mathrm{A}$, the $15 \mathrm{~m}$-bore well at plant B might be contaminated by $18.83 \%$ of leachate and was also supported by lower tritium than that of plant A's monitoring wells. Thus, qualitative mixing of leachate to groundwater that was calculated by deuterium clearly confirmed to electrical conductivity (EC) data in Table 2. The Cibitung River site BG-4d collected nearest to plant $\mathrm{B}$ had a much higher mixing portion than that of BG-1c. This difference could be observed physically by its rather black color. Some resident wells that might be contaminated by leachate were BG-5, BG-10 and BG-1a as shown in the Table 4.

According to mixing calculations using the deuterium data, it was indicated that $6 \mathrm{~m}$ - and $15 \mathrm{~m}$ monitoring wells of plant A in zone-3 had undergone leachate mixture of approximately $33 \%$ and $30 \%$, respectively. The lower portions of leachate mixture to groundwater were also observed in some shallow wells located in housing residences that were confirmed by higher tritium activities.

\section{CONCLUSION}

The physical parameters TDS, EC, and $\mathrm{pH}$ of the collected samples from shallow ground water in the vicinity of the Bantar Gebang landfill indicated that the leachate has contaminated the shallow groundwater. Deuterium content in leachate was significantly higher compared to surrounding groundwater for both the rainy and dry seasons. This result may be due to the leachate having significant evaporation and hydrogen isotopic exchange between leachate water and methane. The ${ }^{18} \mathrm{O}$ shift in the leachate from the local meteoric line was also an indication that the leachate had undergone significant evaporation. Higher tritium activities of leachate may be caused by luminescent paints that were buried in solid waste.

The isotope contents of plant $\mathrm{B}$ in zoneSumur Batu was relatively lower in ${ }^{2} \mathrm{H}$ values and ${ }^{3} \mathrm{H}$ activities compared to those of plant $\mathrm{A}$ in zone-3. This difference may be the result of differences in the age and size of the two waste water treatment plants, i.e, plant B is younger and smaller than plant A. The higher values of both isotopes in monitoring wells indicated that groundwater has been contaminated by leachate. From simple calculation, it was found that the mixing of leachate to groundwater has reached to as high as $33 \%$.

\section{ACKNOWLEDGMENT}

This study was supported by Center for Isotopes and Radiation Application - National Nuclear Energy Agency (BATAN). The author would like to acknowledge the Godang Tua Jaya Company as the executor for Bantar Gebang Landfill for its permission in leachate sampling and local people for their sincere assistances in groundwater collection. The author also greatly expressed the thanks to Agus Martinus in his charge to analyze tritium and Hydrology staffs in Industrial and Environmental Division.

\section{REFERENCES}

1. Anonymous, Plans of waste management, http://bappedajakarta.go.id/images/prediksisamp ahbig.gif. Retrieved in December (2008).

2. Anonymous, Three steps to overcome the waste emergency 13-5-2014, http://m.bekasikota.go.id/read/13259. Retrieved in May (2014).

3. A. Indra Basuki promises to build a green zone in Bantar Gebang, http://tekno.kompas.com $/ \mathrm{read} / 2012 / 12$. Retrieved in October (2014).

4. B.C. Matahelumual, Jurnal Geologi Indonesia 2 (2007) 113.

5. Environmental Management Center, Harmonization of urban waste in order to improve public health, quality of water resources, environment and economy, 
http://litbang.pu.go.id. Retrieved in November (2013).

6. N. Noriko, Ecological review of final dumping in Bantar Gebang - Bekasi, http://tumoutou.net/6_sem2_023/nita_noriko.ht $\mathrm{ml}$. Retrieved in December (2008).

7. Syafalni, M.S. Saeni, S. Hardjoamidjojo, et al., Majalah Batan XXXV (2002) 73.

8. E.R. Pujiindiyati, Atom Indonesia 37 (2011) 76.

9. S.S. Castaneda, R.J. Sucgang, R.V. Almoneda, et al., J. Environ. Radioact. 110 (2012) 30.

10. C.N. Jessica, D.F. Russel and V.H. Robert, J. Geochem. Explor. 88 (2006) 49.

11. K.C. Hackley, C.L. Liu and D.D. Coleman, Groundwater 34 (1996) 827.

12. D.I. Siegel, J.P. Chanton, P.H. Glasser, et al., Global Biogeochem. Cycles 15 (2001) 967.

13. I. Clark and P. Fritz, Groundwater Quality in Environmental Isotopes in Hydrogeology, Lewis publishers Boca Raton New York (1999) 157.

14. Anonymous, Laser spectroscopy analysis of liquid water samples for stable hydrogen and oxygen isotopes - Training course series No.35, IAEA. Vienna (2009) 1.
15. IAEA/WMO, Global Network of Isotopes in Precipitation. The GNIP Database. http://wwwnaweb.iaea.org/napc/ih/IHS_resources gnip.html. Retrieved in June (2013).

16. Wandowo, Final Report of Integrated Excellent Research V Departement of Technology for Environmental Protection 1997-2000, Ministry of Research and Technology - National Research Council, Jakarta (2000) 21.

17. M.J. Baedecker and W. Back, Groundwater 17 (1979) 429.

18. M. Lawson, Isotopic of groundwater contamination: Techniques, applications and considerations, EPA Hydraulic Fracturing Study Technical Workshop on Chemical and Analytical Methods (2011) 9.

19. H. Krouse, Studies on Sulphur Isotope Variations in Nature, IAEA, Vienna (1985) 19.

20. B.G. Katz, Using $\delta^{18} \mathrm{O}$ and $\delta \mathrm{D}$ to Quantify Ground-water/Surface - water Interactions in Karst System of Florida, http://www.acwi.gov/monitoring/conference /..../papers/19-katz.html. Retrieved in July (2013). 